IN RETROSPECT

\section{The Prince}

John Whitfield finds resonance with today's behavioural sciences in Niccolò Machiavelli's great Renaissance political treatise, begun five centuries ago this month.



Machiavelli knew that an individual's fate is inseparable from that of his or her group's.
A s a high-ranking minister and diplomat in the Florentine republic, Niccolò Machiavelli might have been surprised by his enduring reputation as the prophet of a philosophy in which winning is all and scruples are for suckers. His classic work The Prince, written 500 years ago, is a foundational text of political science with continuing relevance for one of today's hot research topics. Since its publication five years after the author's death, it has also been infamous for severing the link between politics and morality.

The Prince can be read both as a guide to how men acquire and maintain power and a book about how societies work how states can create the public spirit they need to survive. Today, this is the point where disciplines such as game theory, evolutionary psychology and behavioural economics meet, and where researchers still argue about human nature and how their academic insights can translate into public policy.

Machiavelli based his case on observations made in the courts of Europe during 14 years in government, as well as readings in classical history. The Prince was a revolutionary twist on the medieval and Renaissance genre known as 'mirrors of princes', offering advice to rulers: it contains few references to Christian virtue, instead emphasizing evidence-based policy. Chapter by chapter, the book guides the neophyte dictator through problems such as the best way to treat conquered states, how to plan for a siege and the right image to project to the masses.

Machiavelli is particularly interested in upstart rulers who have risen through daring and force. If The Prince has a hero, it is Cesare Borgia, who in around 1500 cut a swathe across Italy using murder and trickery. Borgia also temporarily unified a good part of the peninsula under a nativeborn ruler - and so, in Machiavelli's eyes, achieved more good than many more conventionally virtuous leaders.

This tough-mindedness reflects the turbulence of Machiavelli's time in government, which began in 1498. He saw Florence and other Italian states divided by conflict and invaded by foreign powers such as Spain and France. His political career ended in 1512, when the Medici family and the 'warrior pope' Julius II retook Florence and abolished the republic. In early 1513, Machiavelli was tortured on suspicion of conspiring against the Medicis and then released without charge. In July, he began to write what would be The Prince. Some six months later, he presented it to the Medicis, as one of history's more remarkable but less
The Prince NICCOLÒ MACHIAVELLI 1532. successful speculative job applications.

A lot of what we have learned since Machiavelli 


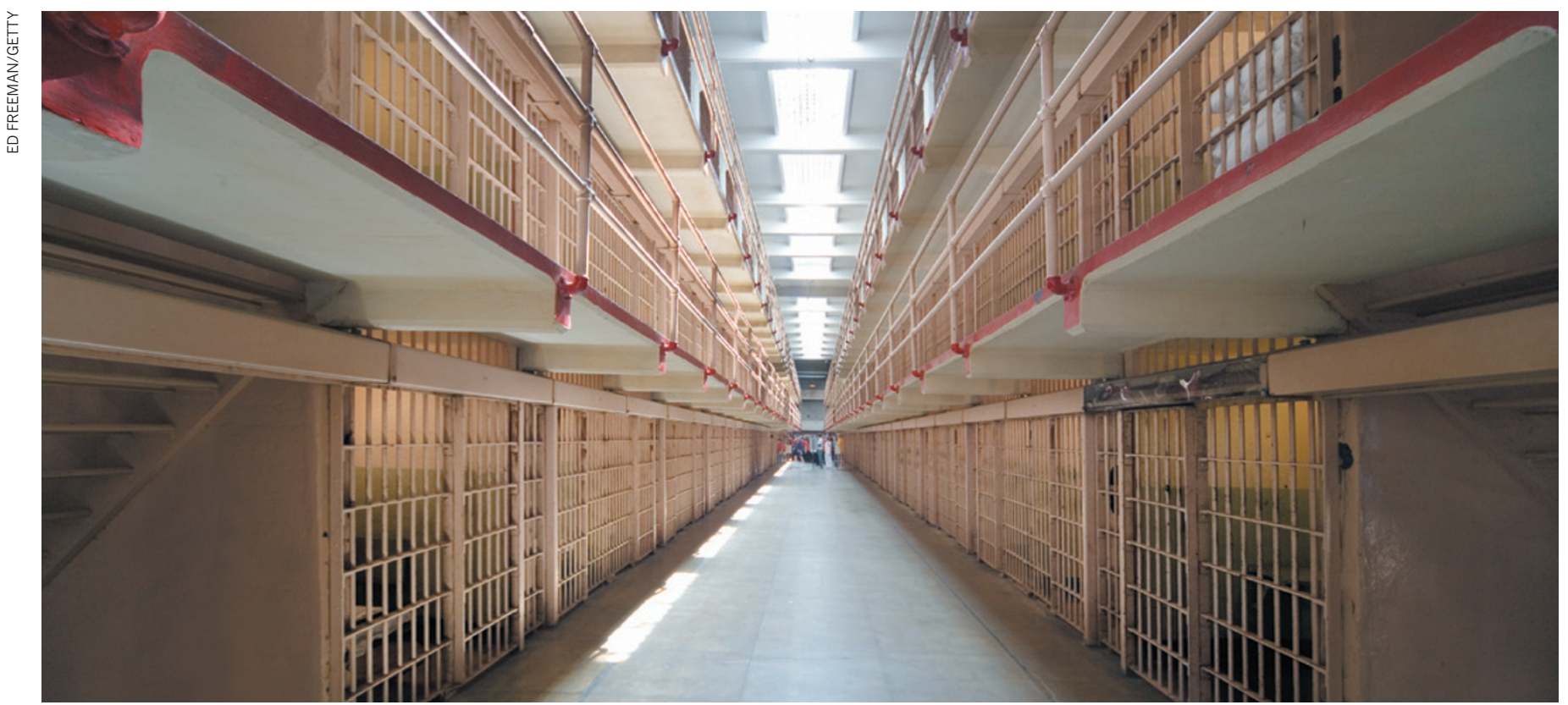

Punishment is costly and invites retaliation, so why do we do it?

about our species' social behaviour can be summed up by saying that humans' exceptional ability to cooperate with members of their own group gives them an exceptional ability to compete with other groups. This is called parochial altruism. Humans are more helpful to each other than almost any other species, and their societies are more egalitarian. But beyond the edge of a group, cooperation has a tendency to become wellorganized brutality.

The Prince is a treatise on parochial altruism. Machiavelli knew that an individual's fate is inseparable from that of his or her group, and had seen that weak states fell prey to those that were stronger and better organized. You don't have to squint too hard to see the book not as a self-help guide for despots, but as an investigation of how societies can build and maintain the public good in an unconducive political environment.

For example, Machiavelli's prescriptions for resisting invasion and suppressing plots focus on building collective strength. Even for an autocrat, he argues, success comes through good government. The "friendship of the people", he says, is a ruler's best insurance against conspiracies, and a citizen militia is a more effective fighting force than foreign mercenaries. He gives more, and harsher, advice on dealing with outsiders - "a Prince", he writes, "must have no other object or thought ... except war" - than he does on domestic policy, where he recommends rewarding talent and enterprise, not overtaxing one's subjects, and staying away from their property and women.

Beyond the city walls, the gloves are off. For example, he says: "You can be more liberal with what does not belong to you or your subjects." But Machiavelli understood

that boundaries can be manipulated. He advises that the best way to hold a conquered territory is to go and live there, so that its group becomes yours. He yearned for Italy's unification more than three centuries before it happened.

Even when Machiavelli famously advises that fear, and not love, is the safest guarantee of loyalty, he highlights the wider benefits of a fearsome reputation. Cruelty should be "as far as possible turned to the good of one's subjects". He writes that "by making an example or two", a ruler "will prove more compassionate than those who, being too compassionate, allow disorders which lead to murder and rapine.

"The Prince can be read both as a guide to how men acquire and maintain power and a book about how societies work." These nearly always harm the whole community, whereas executions ordered by a prince only affect individuals."

This is similar to current debates over why individuals and societies punish wrongdoers. It is unclear why people are so keen to mete out punishment, which is costly, uses up time and energy, and invites retaliation. And if a punished person reforms, the benefit is spread across the whole community. This creates an incentive to let other people do the punishing.

Researchers disagree over the selective forces that favour punishment. Those with a background in evolutionary biology, such as Manfred Milinski, tend to view it as a tool that primarily serves individuals, by displaying strength, winning friends and deterring challengers. Others, generally economists, including Ernst Fehr, emphasize the benefits to groups of suppressing antisocial behaviour. In this view, known as strong reciprocity, punishment arose and spread because groups that did it outcompeted groups that did not.

Machiavelli would probably have taken the former, neo-Darwinian, view that to survive, every altruistic act ought to yield an individual benefit. Despite his republican sympathies, he wrote that men were "ungrateful, fickle, liars and deceivers", who "shun danger and are greedy for profit".

But believers in strong reciprocity point instead to the wealth of evidence that instincts for fairness, sharing and justice are deeply rooted in human behaviour. In a 2010 lecture series (due to appear as a book) at Yale University titled 'Machiavelli's mistake', one of them - economist Samuel Bowles of the Santa Fe Institute in New Mexico - argues that when governments, assuming people to be self-interested, focus on material incentives as a means of encouraging good behaviour, they risk undermining the prosocial behaviours that underpin society.

Given the breadth of Machiavelli's writing, and his diligence as a public servant, it is unjust that his name epitomizes manipulative selfishness. Even so, how we run our societies still depends on understanding to what extent people are naturally Machiavellian and - more importantly - which environments make them more so.

John Whitfield is the author of People Will Talk: The Surprising Science of Reputation, and comment editor of Research Fortnight and Research Europe. e-mail:j.a.whitfield@gmail.com 